Marek Pawlak*

DOI: 10.2478/v10241-012-0005-7

\title{
An interlocking-directorates monitoring system
}

\section{ABSTRACT}

The subject of the study was interlocking directorates in Polish joint stock companies. In order to explore this area a monitoring system has been developed which consists of a database and query system. Data is automatically introduced from printed announcements into the MySQL database using PHP scripts.

The phenomenon of interlocking directorates in Polish joint stock companies is comparable with other countries. Board members in Poland are significantly younger than, for example, in the USA. Women constitute an important group of board members. Insurance companies and investment funds are closely connected with other companies, but banks are not.

The monitoring system developed enables us to identify who is, and who was, a board member of every joint stock company. It also enables us to identify, for every person, which board he or she now serves on, and has served on, in the past. The system also enables us to produce different reports concerning, for example, changes in certain indexes in subsequent years. The system is also accessible via the Internet.

KEYWORDS: Interlocking directorates, board of directors, database.

* Correspondence regarding the paper should be sent to: Prof. Marek Pawlak, The John Paul II Catholic University of Lublin, Institute of Economics and Management, Al. Racławickie 14, C-558, 20 - 950 Lublin, e-mail: marek.pawlak@kul.pl 
THE NOTION OF INTERLOCKING DIRECTORSHIPS

Generally there are two models of board organisation. The first is the unitary board model in which all legal responsibilities are vested in one board headed by a chairman. This model is used, for example, in such countries as the USA, Britain and Ireland. The second is the two-board management model, in which there is an executive board and a management board. This model is used in such countries as Germany, Austria, the Netherlands, Switzerland and Poland. The distinction between the two is very close to the distinction between the executive and non-executive directors in the Anglo-American model, and therefore the two models can be considered together (Mac Canna Leo, Brennan Niamh, O'Higgins Eleonor, 1998).

Many executive (inside) directors and non-executive (outside) directors hold only one directorship, but others, particularly outside directors, hold more than one directorship. The situation in which one inside or outside director serves at the same time in two corporations is called an 'interlocking directorship', and this director is called an 'interlocking director'. Interlocking directorships (directorates) are more common in groups of outside directors, as they include a number of public and political figures who are recruited from other companies, and especially from the banking, insurance, and investment sectors (Scott John, 1991).

An additional, and more specific, phenomenon is the socalled 'reciprocal interlock', particularly the CEO reciprocal interlock. This occurs when the CEO of firm $i$ serves as a director of firm $j$, and the CEO of firm $j$ serves as a director of firm $i$ (Fish, White, 2005).

The phenomenon of interlocking directorships can be interpreted in different ways depending on the goal of the interpretation, who performs this interpretation, and when this interpretation is made. 
The first interpretation of the concept of interlocking directorships comes from political science. From this point of view they are interpreted as "traces of power", "class hegemony", and "as vehicles in the accumulation of capital along an integrated financialindustrial axis" (Carroll William K., Alexander Malcolm, 1999). As a result of this, researchers have been worried about "the concentration of power in too few hands" (Mac Canna Leo, Brennan Niamh, O'Higgins Eleonor, 1998).

Brayshay, Cleary and Sellwood (2006) described the web of links between firms and individual economic actors as "power geometry", driving forward and shaping the internationalisation of business activity. Directors are recruited from the upper class and they form a corporate elite (inner circle) of multiple directors of similar social background (Mac Canna Leo, Brennan Niamh, O'Higgins Eleonor, 1998). Their directorships spread throughout the economy, and they form the business elite of corporate decision makers with power and influence across the business system as a whole (Scott John, 1991) (Burris Val, 1991). For example, in France the majority of top managers graduate from two schools: the Ecole Nationale d'Administration and the Polytechnique. The graduates of these two schools are capable of imposing their power by the intermediary of a clan structure. 22 such 'valuable' persons are directors out of a total of 214 board of directors. They determine 4 clans of French firms orbiting, respectively, around Paribas, Suez, UAP, and Lazard Frère (Yeo, Pochet, Alcouffe, 2003).

The second interpretation of the concept of interlocking directorships comes from the social sciences. Here they are interpreted as social relationships, and in the studies carried out some sociological tools have been used, for example the Social Network Analysis (SNA) technique (Mac Canna, Brennan, O'Higgins, 1998).

The third interpretation comes from management sciences. Here they are interpreted as an instrument of corporate control, 
or as devices to monitor firms. For example, Barbi (2000) understands the interlocking directorship phenomenon "as a legal instrument in order to make the control position in a firm steadier". The multiple positions of executives create links between corporations. These links can contribute to considerable stability in corporate governance.

The interpretation proposed by Theisen (2000) also comes from management sciences. He distinguishes two kinds of interlocking directorships. In his opinion, interlocking directorships can, firstly, result from the accidental overlapping of business activities conducted by two people and, secondly, they can also reflect the conscious and intentional manner of establishing links between enterprises at the level of the people involved, or be geared towards intensifying or stabilising existing links. These links can either be at the level of the owners, and in this case we can speak of "interlocking ownerships", or at the level of the directors, and in this case we can speak of "interlocking directorships". Theisen wrote: "Interlocking ownerships are typical for medium sized enterprises and family enterprises. Interlocking directorships occur irrespective of company size" (Theisen Manuel René, 2000). From the economic point of view, such a solution suffices to constitute the basis for the co-ordinated management of two or more companies.

\section{INTERLOCKING DIRECTORSHIP STUDIES IN THE PAST}

Interlocking directorships have been the subject of empirical studies for years. Brayshay, Cleary and Selwood (2006), studied the links between companies in the 1930s. In their opinion, the degree of complexity of connections that created a potential indirect link between two (or three) firms, and the interlaced personal networks of contacts, appeared to have increased sharply between the early 1900s and the 1930s. They examined the back- 
grounds and shared spaces of interactions of just one powerful member of Britain's 1930s multinational corporate elite: Patrick Ashley Cooper. Cooper was, himself, the connection that interlocked the London boards of ten companies of which he was a director between 1931 and 1932. Multiple directorships were common; the average number held by each member of the group studied was a little over six.

Burris (1991) investigated "the political behaviour of corporations and corporate elites who occupy pivotal locations within networks formed by interlocking directorships". He studied how individuals (members of the "inner circle") contributed to the national Presidential election in the USA in 1972, and how corporations contributed to the national Presidential election in 1980. The results of these studies indicate that as the number of directorships increases, the political behaviour of individuals becomes more conservative. On the contrary, highly interlocked corporations are less conservative than average.

The studies described by Hughes, Scott and Mackenzie (1977) concern the comparison between the number and the changes of interlocking directorships in Norway, Sweden and Scotland. They have shown that the number of interlocking directorships decreased in Scotland from the year 1906 to the year 1973. They explain this fact by suggesting that "whilst the earlier period was marked by a clustering of formally independent companies through interlocking directorships, the later period involves the existence of a large conglomerate group of enterprises between which there is the need for only a low level of interlocking". In Scotland in 1906, 21.6\% of all directors held two or more directorships; by 1973 this figure had fallen to $10.5 \%$.

Carroll and Alexander (1999) examined the top 250 corporations and associated networks of interlocking directorates in Canada and Australia in the 1990s. They found that, in Australia, 226 directors and executives hold at least two corporate positions in the Top 250, while in Canada the boards and executives 
of the top 250 companies contained 560 such interlockers. In all, the 226 Australian interlockers carried 596 interlocks, while the 560 Canadian interlockers carried 1,994 interlocks. In Australia, the mean board size was 7.7, and the mean degree of interlocked boards 3.7; in Canada, the mean board size was 13.2, and the mean degree of interlocked boards 11.3.

Scott (1991) constructed a general model of power in intercorporate networks, in which there are three types of relationships: personal, capital and commercial. The most important types of personal relationships are interlocking directorships, and the kinship relationship amongst the individuals involved in various corporations. Scott studied these relations in different companies in America, Europe and Asia. Interlocking directorships are present in every economy, but in his opinion there are different reasons to create these networks.

Mac Canna, Brennan and O'Higgins (1998) described studies concerning interlocking directorships in the 250 biggest Irish companies. They also compared the results with previous studies conducted by Stokamn, Zeigler, and Scott in 1985. In Ireland, there are relatively fewer multiple directorships (only $8 \%$ in the sample studied) than in other countries examined by Stokamn, Zeigler, and Scott, and in Ireland there are fewer directorships held by one director (only 1.11 directorships per one director). Women held only $4.4 \%$ of the total directorships in Ireland.

Barbi (2000) studied interlocking directorships in Italian companies. The data set was created from the total directory appointments in listed companies from 1983 to 1998. She considered 15,219 directory appointments concerning 232 companies and 855 directors. The information relating to each "director" concerned the type of appointment, and the entry and exit time. Three different periods of time were studied. Barbi concluded that, basically, the phenomenon of the interlocking directorate 
is decreasing. There is also a decreasing trend in the number of links among companies.

Ong, Wan and Ong (2003) studied interlocking directorates in listed firms in Singapore. They took into consideration 295 listed companies on the Singapore Stock Exchange in 1997. The results of these studies show that the number of interlocking directorates is positively correlated with board size (a Pearson correlation coefficient of $R=0.280$ ), indicate whether it is a financial or non-financial institution $(R=0.228)$, and show the firm's performance measured by returns on assets $(R=0.101)$, returns on sales $(R=0.132)$, returns on equity $(R=0.031)$, as well as profit before tax (0.034). But the correlation coefficients are not high. The authors of this study conclude that interlocking directorates help to reduce the environment of uncertainty, enhance organisational effectiveness, and improve corporate performance.

Robins and Alexander (2004) studied interlocking directorships in the US and Australia using bipartite graphs. The data sets comprised the affiliation of directors in the top 200 nonfinancial, and top 50 financial, corporations in each country in 1996. They took into consideration only directors who possessed more than one seat. In the US, each board had an average of 5.45 interlockers, while each interlocker held an average of 2.55 board seats. They concluded, among other things, that multiple interlocks may arise from social (class-based) processes. New members with external connections may be introduced to corporations by existing board members who have experience with them on other boards. These multiple connections can also reflect intercorporate relationships of trust and more formal alliances.

Theisen (2000) describes the studies concerning interlocking directorships (Personelle Verflechtungen) which have been carried out in the 100 largest German corporations and which identified 840 interlocking directorships on the board of directors level. 
Interlocking directorships are also held by people who have finished their industrial activities. Brickley, Linck and Coles (1999) have studied what happens to CEOs after they retire. They found that, for the CEOs who leave the firm aged 64, 65 or 66, "the average number of board seats held two years after retirement is 2.48 . Nearly $88 \%$ of these CEOs hold at least one board seat, $42 \%$ hold three or more seats, and just over $28 \%$ of the retired CEOs hold four or more seats." "At the extreme, Allen F. Jacobson served as a director of eleven large corporations two years after retiring as $C E O$ of Minnesota Mining and Manufacturing Company." The average annual pay for an outside director serving on a single board is $\$ 44,000$. Mr. Jacobson received approximately $\$ 595,000$ for his board services. "Many companies also provide directors with pension plans, insurance, and other benefits and perquisites". Additionally, a chairman often receives hundreds of thousands of dollars for serving in this position.

Research which has been recently carried out has had much more sophisticated goals. For example, Fich and Shivdasani (2007) investigated "the reputation impact of financial fraud for outside directors based on a sample of firms facing shareholder class action lawsuits". The sample of firms sued contained 1,241 outside directors, 396 of which held directorships in firms other than the firm sued for fraud. They found "a dramatic decline in the other directorships held by these outside directors". On average, outside directors of firms sued experienced a reduction of about $50 \%$ in the number of other directorships held, and $96 \%$ of outside directors who sit on another board lost at least one directorship within three years following the lawsuit. The direct financial value of lost directorships is estimated to be approximately $\$ 1$ million. The average number of other directorships held by outside directors of firms sued was as high as 0.96 in the year of the lawsuit. After three years this number had declined to 0.47.

Harford (2003) investigated, among other things, the effect of takeover bids on the number of future board seats held by 
target directors. In his opinion, there are at least three main factors plausibly at work in the market for directors. Directors are sought who (1) have experience and a reputation for maximising shareholder value, (2) are passive directors with a reputation for loyalty to management, and (3) have good personal networks - directorships are partially determined by who knows whom. Harford studied a sample of 1,091 directors from 91 Fortune 1000 firms which were targeted from 1988 to $1991.29 \%$ of inside directors and 58\% of outside directors held other Fortune 1000 directorships. The mean age of all directors was 59.89. The mean number of additional directorships was 1.94 (for inside directors it was 1.01, and for outside directors 2.36). The mean board size was as high as 11.99. Harford's studies documented that only $10 \%$ of the outside directors targeted were typically retained following a completed merger.

Jiraporn, Kim, Davidson (2008) examined the impact of multiple directorships on the diversification discount over the period from 1998-2002 in the USA. The sample consisted of about 700 big firms (this number changed in subsequent years), which were divided into focused and diversified ones. The average board size was 8.61, and the average number of other directorships was 0.86 . Diversified firms have, on average, significantly larger boards than focused firms. The average number of other directorships was larger for diversified firms (0.95) than for focused firms (0.75). Board members of diversified firms were busier than those of focused firms. The results of this study show that busy directors allow managers to diversify the firm unnecessarily. Overcommitted board members appear to diminish the firm's value.

Reciprocal CEO interlocks were also the subject of study.

Yeo, Pochet and Alcouffe (2003) studied a sample of 246 big French corporations. The mean board size was 9.48 , and $80 \%$ of CEOs had achieved the position of chairperson. $57 \%$ of the firms in the sample studied had at least one reciprocal CEO interlock 
relationship in French companies. CEO reciprocal interlocks ranged between zero and sixteen for the firms sampled. CEO reciprocal interlocks were positively correlated with the firm's size. Also, the relationship between the ROA of the CEO's board and the number of CEO reciprocal interlocks was significantly positive. The overall results of these studies are that CEO reciprocal interlocks are more likely to occur in firms where a blockholder is present on the board, more likely to be formed if CEOs hold more outside directorships, and more likely to arise in a highly valued firm with more growth opportunity.

Fich and White (2005) studied CEO reciprocal interlocks in US corporations. They used a sample of 576 companies from the Forbes " 500 " list for 1991 . The data covered 9,804 director seats held by 7,519 individuals. The mean board size was 12.88 (3.78 inside directors, 7.88 outside directors, and 1.23 gray directors). The mean age of the CEOs was 56.56 years, and the mean CEO tenure was 8.44 years. $12.15 \%$ of the firms in the sample had at least one CEO interlock relationship. The results of these studies show that a reciprocal CEO interlock is more likely to be an instrument that enhances a CEO's private interests, and is less likely to be a corporate governance feature for advancing the interests of the company's shareholders.

On the basis of these short studies of the literature, the following conclusions can be drawn:

1) Interlocking directorships have existed as a phenomenon for many years, and they have also been the subject of studies for many years.

2) They are interpreted as the "social relationships of class hegemony", "vehicles in the accumulation of capital", "social network between companies", or a legal instrument which helps to control a firm, and they constitute the basis for the co-ordinated management of two or more companies.

3) The subject of earlier research was the extent and changes in interlocking directorships, while the subject of the latest re- 
search was the influence of, for example, financial fraud or a takeover bid on the number of directorships.

4) A non-trivial phenomenon are CEO reciprocal interlocks. They are particularly widespread in French and US corporations.

\section{THE DATABASE AND ITS DEVELOPMENT}

The subject of the studies described here were interlocking directorates in Polish joint stock corporations. Every corporation is obliged to publish data concerning changes in its board in the print journal called the Business and Court Gazette (BCG). The idea arose to move the data from these announcements onto a computer database.

The database developed comprises a set of three tables. The relationship between the tables is shown in Figure 1. The first table, 'Main', consists of nine fields which describe entries in the BCG. The second table, 'Persons', consists of five fields describing people. This table contains the personal data of people with a personal identification number [PESEL], and those who have not been assigned such a number. This, however, makes it impossible to use the PESEL number to search the database and identify the people listed in the table. Therefore, the problem was solved by each person receiving a unique numerical identifier (person_id) which is generated by the computer system. The third table is used to identify companies. It contains the number of the National Court Register (KRS) - the same as in the first table - and the name of the company. The KRS number is unique for each company, which allows for accurate identification.

As we can see in Figure 1, the database fulfils the requirements of the second normal form (2NF). In order to fulfil this condition, (1) the data that apply to multiple rows of a main table are placed in separate tables, and (2) relationships are cre- 
ated between these new tables and their predecessors through the use of foreign keys. The database does not fulfil the requirements of the third normal form.

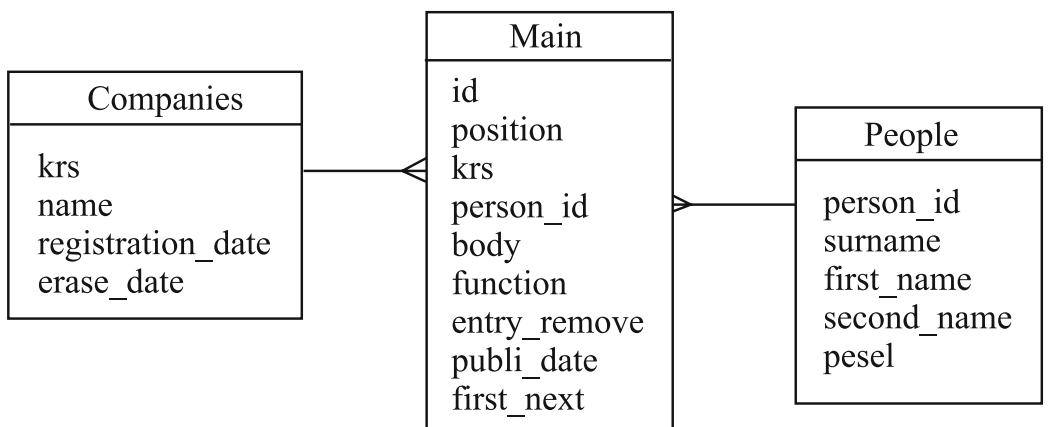

Fig. 1. The relationship in the database.

The extraction technology

The extraction of text fragments and their transferral onto a computer database is carried out according to the following steps:

1. Choosing pages from BCG which concern joint stock companies.

2. Scanning the selected pages.

3. Converting the text from.pdf format to.txt format.

4. Selecting the text fragments that concern joint stock companies.

5. Checking the text and correcting mistakes.

6. Applying PHP scripts for the extraction of text fragments.

7. Checking the data and correcting the mistakes.

An example of a page from BCG, which contains data concerning joint stock companies, is presented in Figure 2. In this case, they are so called 'subsequent announcements' concerning changes in boards. As we can see, only a part of this page is occupied by announcements concerning joint stock companies ('Spółki akcyjne'). On the page presented there are also an- 


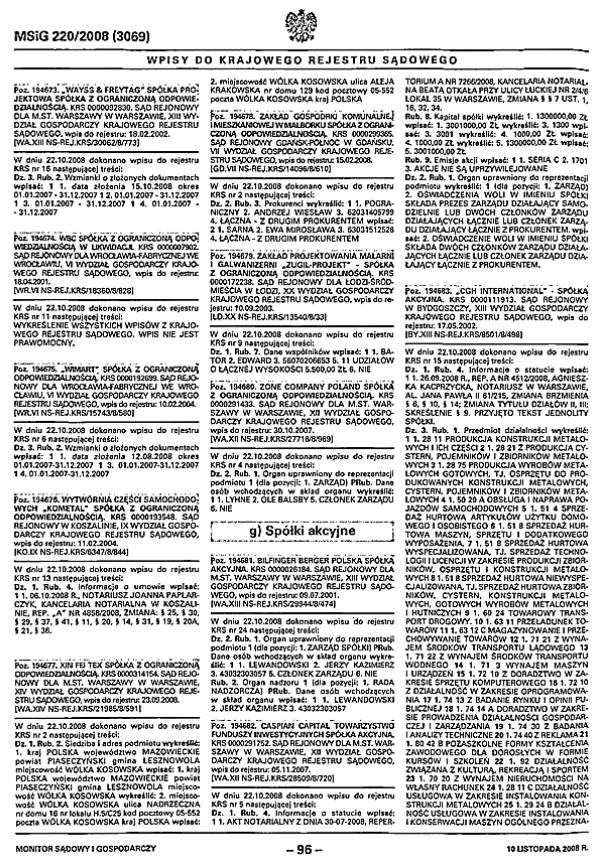

Fig. 2. An example of a page from BCG.

nouncements concerning limited liabilities companies, which in this case are not the subject of interest.

The key element of the process is the conversion of.pdf files into text files, because there are errors which are difficult to eliminate. There are two kinds of errors:

1. Errors which appear in BCG announcements and are made by the Gazette's editors.

2. Errors which are made while converting the text from. pdf format to.txt format. These errors result from an inaccurate printing of the text. Inaccurate printing causes Fine Reader to make mistakes during text recognition. Errors can be made in particular during the recognition of names, surnames, company names, and foreign languages. 
Additionally, we must remember that, despite establishing the format of announcements, it has been changed in subsequent years. These kind of changes took place during the period in question, from March 2001 to October 2008.

\section{The application of PHP scripts}

PHP (Hypertext Pre-processor) does not have many complex functions in the conversion of character strings, but those which are available enable the application of this language in the situation in question. In particular we can enumerate the following functions:

1. strpos(\$haystack,\$needle) - returns the numeric position of the first occurrence of \$needle in the \$haystack, if \$needle is not found, strpos() will return Boolean FALSE.

2. substr(\$string,\$start[,\$length]) - returns the portion of \$string specified by the \$start and \$length parameters. If \$start is non-negative, the returned string will start at the \$start 'th position in \$string, counting from zero. If \$start is negative, the returned string will start at the \$start 'th character from the end of \$string.

3. substr_replace(\$string,\$replacement,\$start[\$length]) - replaces a copy of \$string delimited by the \$start and (optionally) \$length parameters with the string given in \$replacement.

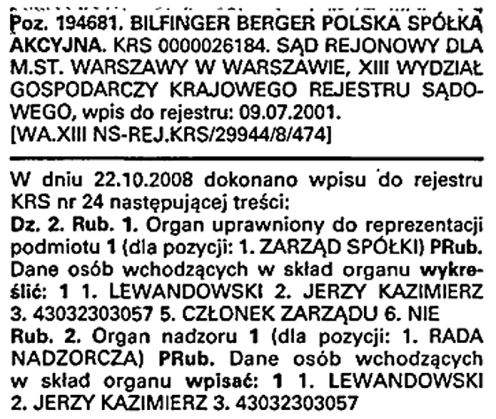

Fig. 3. An announcement concerning a joint stock company. 
We can look again at the page with the announcements shown in Figure 2. One of the announcements concerning joint stock companies is shown in Figure 3.

After converting this announcement into text format we obtain the following string of characters:

POz. 194681. BILFINGER BERGER POLSKA SPÓŁKA AKCYJNA. KRS 0000026184. SĄD REJONOWY DLA M.ST. WARSZAWY W WARSZAWIE, XIII WYDZIAŁ GOSPODARCZY KRAJOWEGO REJESTRU SĄDOWEGO, wpis do rejestrtt 09.07.2001. [WA.XIII NSREJ.KRS/29944/8/474] W dnit 22.10.2008 dokonano wpisu do rejestru KRS nr 24 następującej treści: Đz. 2. Rub. 1. Organ uprawniony do reprezentacji podmiotu 1 (dla pozycji: 1. ZARZADSPÓŁKI) PRub. Dane osób wchodzących w skład organu ykreślić: 1 1. LEWANDOWSKI Z. JERZY KAZIMIERZ 3. 43032303057 5. CZLONEK ZARZADU 6. NIE Rub. 2. Organ nadzoru 1 (dla pozycji: 1. RADA NADZORCZA) PRub. Dane osób wchodzących w skład organu wpisać: 1 1. LEWANDOWSKI z. JERZY KAZIMIERZ 3. 43032303057.

Currently, we can apply PHP scripts in order to extract the parts of this announcement that are of particular interest to us. Here, we can take advantage of the fact that these fragments start and end with some distinctive characters or string of characters. The principle of extraction is shown in Figure 4, where the letters $U, X, Y, Z$ denote these distinctive characters. Strings which are moved onto the database are underlined. Strings which control the extraction procedure are crossed out. Sometimes a string is simultaneously underlined and crossed out.

For example, the fragments of the announcement concerning changes in the management board (insiders) start with the string 'Dz. 2. Rub. 1.' and finish with the string 'Rub. 2.'. Hence, our $Z={ }^{\prime}$ Dz. 2. Rub. 1.' and $Y=$ 'Rub. 2.'. The fragments of the text which are chosen according to this rule may then be registered in the MySQL database. 


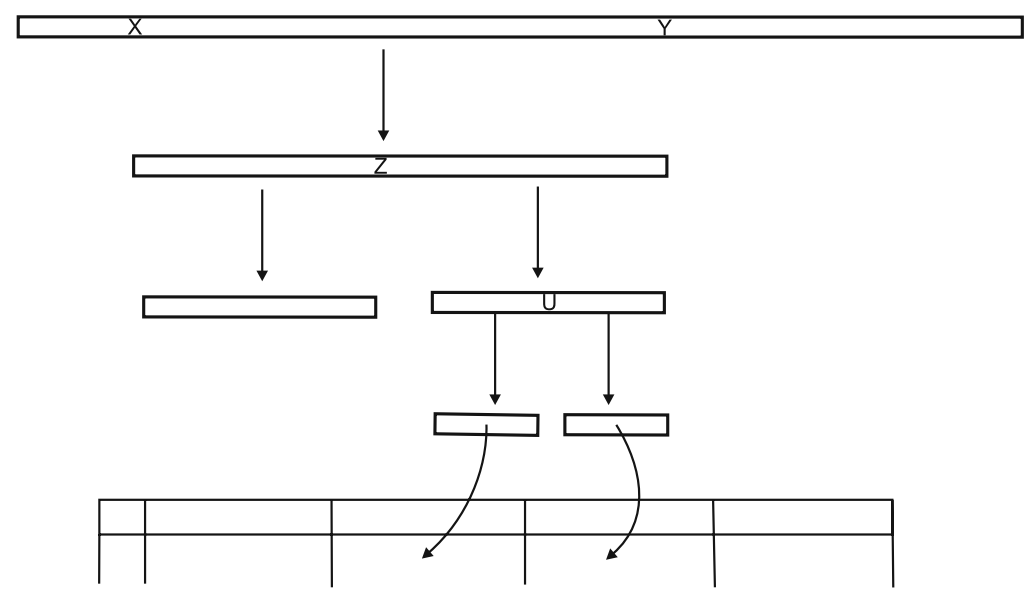

Fig. 4. The principle of information extraction.

Every day there are several pages of announcements in the BCG concerning joint stock companies. By combining several pages of announcements published in one month, it is possible to create a text file which is subsequently analysed prior to registration in the database. A text file which contains announcements from one month usually comprises more than 200 pages.

\section{THE RESULTS OF STUDIES}

As of 31 October 2008, all changes in the composition of Boards of Directors in Polish joint stock companies made during the period from March 2001 to October 2008 had been recorded in the database, i.e. 173,972 announcements. The same number of entries was therefore made in the first (main) table. These announcements referred to 74,460 people (this is the number of entries in the second table), and 7,881 companies (i.e. the number of entries in the third table). At present, the database is regularly updated to include data from the previous few months. Assum- 
ing that the database contains data from at least five years, a full picture of the composition of boards for all Polish joint stock companies can be obtained. It is worth bearing in mind that the term of office for board members cannot exceed five years.

On the basis of the data collected in the database so far, it is possible to make some conclusions concerning interlocking directorships. It must be stressed that in Poland there is no legal restriction concerning the number of interlocking directorships. The situation is the same in Italy (Bianchi, Bianco, Enriques, 2001). But restrictions concerning the number of multiple directorates are in place in Germany (a maximum of 15 directorates), and in France in regulated companies (max. 3 outside directorships) (Yeo, Pochet, Alcouffe, 2003).

\section{Membership numbers in the bodies of authority}

On the basis of the collected data, we can work out the average number of members in certain bodies of authority. The board of directors of Polish joint stock companies on average consists of 6.25 members (1.99 inside directors and 4.26 outside directors). $13 \%$ of the people in the database are foreigners (people who do not possess a PESEL number). About $26.6 \%$ of the people in the database are women, but sex may be identified only for people who possess a PESEL number. The average age of an inside director is 47.26, whereas that of an outside director is 47.49 .

\section{The directors' age}

As of October 2008, there are 74,460 people in the database. Only a part of this group, 35,885 people, is still active; that means they are members of boards. During the period from March 2001 until October 2008 the age of people who were introduced as board members was still changing. This is shown in Figure 5. As we can see, age decreased in subsequent years but this trend changed in 2008. 


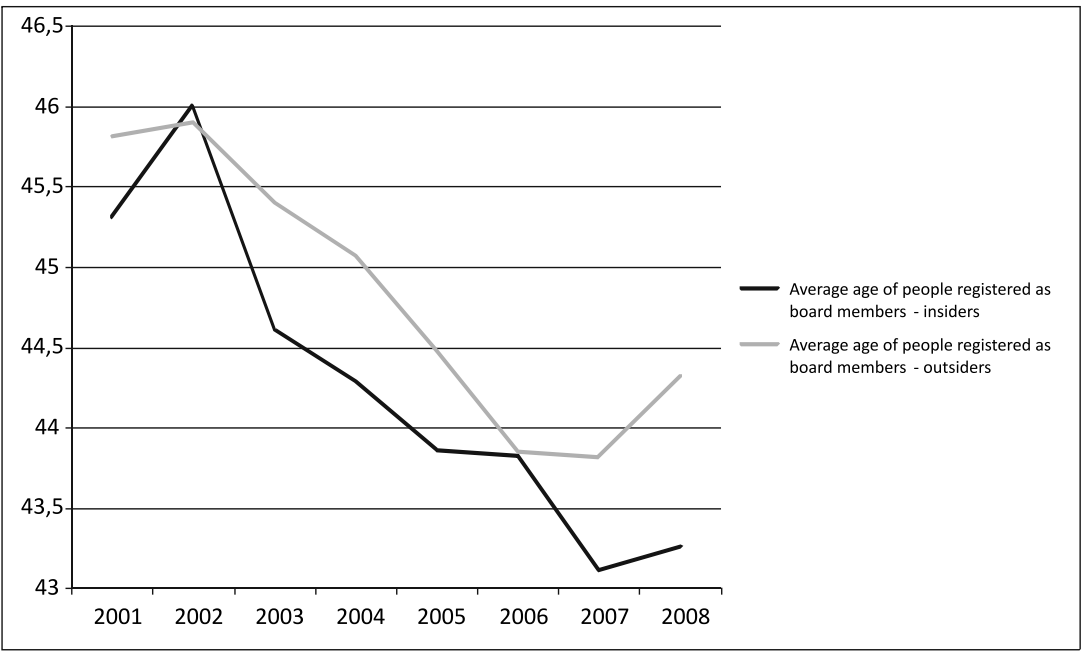

Fig. 5. Average age of people introduced as board members in subsequent years.

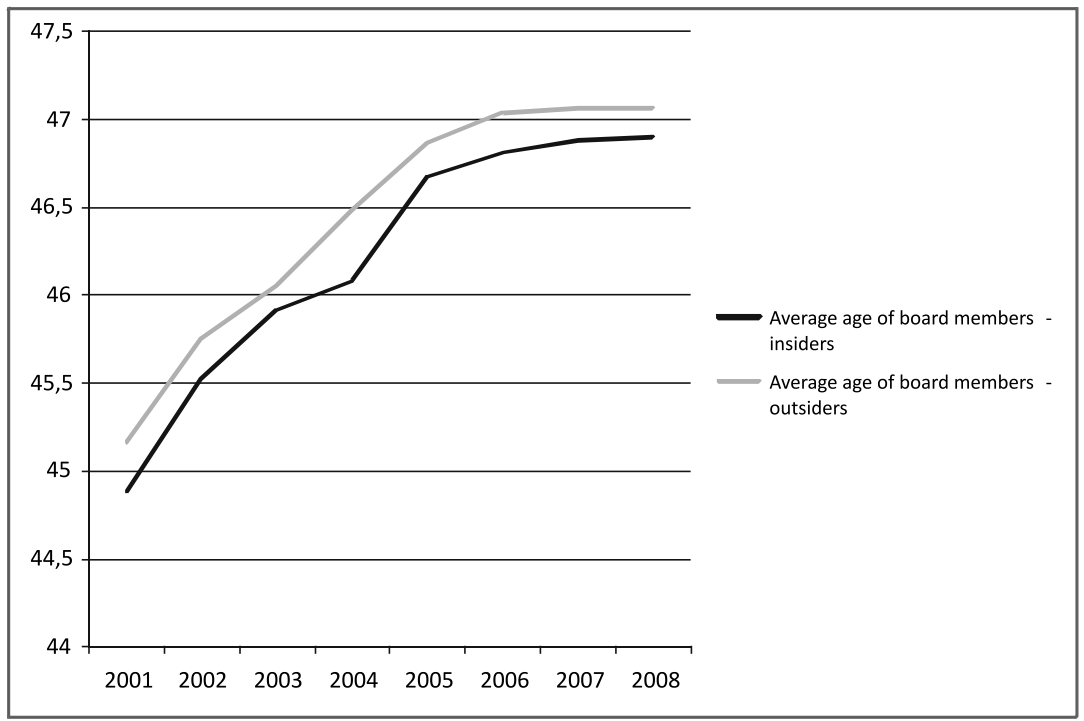

Fig. 6. Average age of board members in subsequent years. 
At the same time, the average age of board members increased, as is shown in Figure 6.

One explanation of this effect may be the still increasing age of people who are board members. But there is also another effect which is shown in Figure 7. We have here the number of people of a particular age in subsequent years. Every curve represents one year. As we can see, the shape of the curves still changes. Between the years 2001 and 2008 it rose, and is still increasing for the group of 'young' people aged about 35 years old. Besides this 'younger' group, there is a second 'older' group aged about 52 , which is becoming older and older, and at the same time is decreasing. The 'older' group, however, still dominates. So, we can talk here about the 'generation change'.

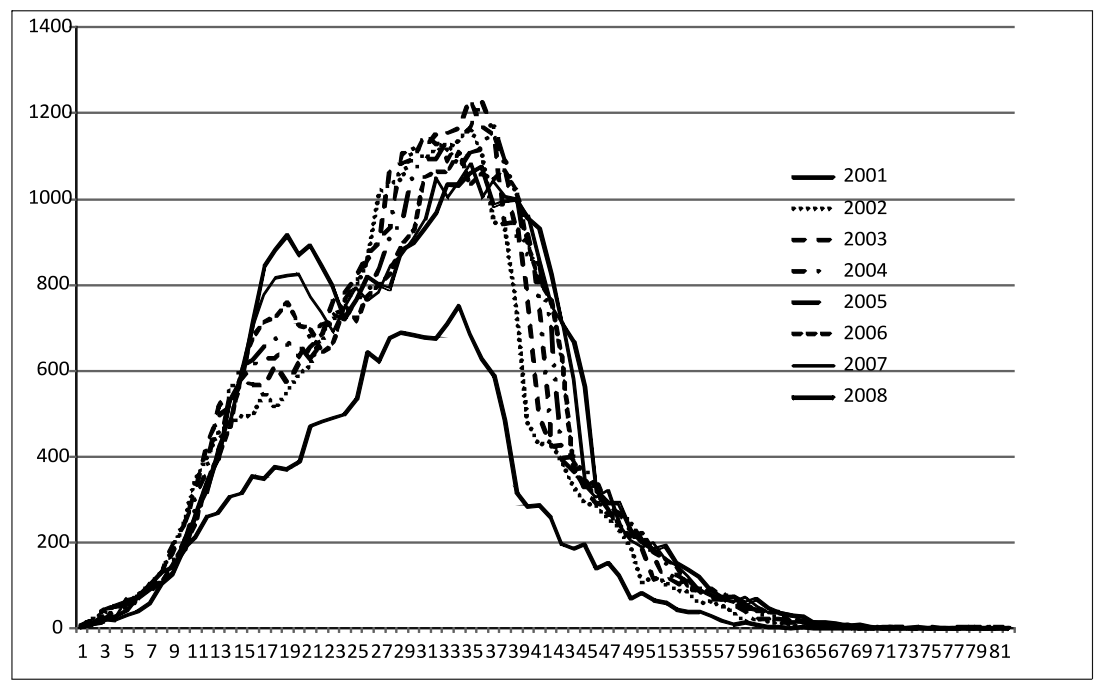

Fig. 7. Board members' age frequency in subsequent years.

Number of mandates

In Poland there are no restrictions concerning the numbers of mandates that can be possessed by one board member. An 
illustration of this phenomenon is shown in Figure 5. The data concern only joint stock companies, and shows the situation in October 2008.

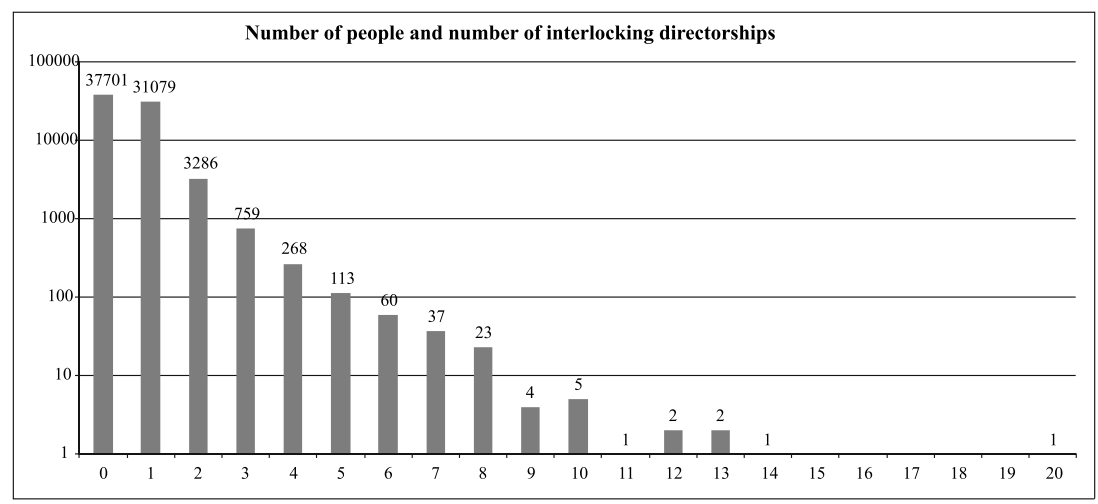

Fig. 8. The number of people and the number of directorates.

As we can see, there are 37,701 people in the database who did not possess any directorates in November 2008. 31,079 people possessed only one mandate, 3,286 two mandates and so on. One person possessed 20 directorates.

Directors' age and the number of mandates

There is an opinion presented in the literature, that the more experienced people possess more mandates. To verify this opinion, we can analyse the number of directorates which people of a particular age possess. We can study this dependence for each one of the 31,673 people who are board members and who possess a PESEL number enabling us to quantify the person's age.

An estimation of the least-square regression line gives the following result:

$$
\bar{Y}_{c}=a+b X=1.297-0.0018 X_{i}
$$


As $b$ is very close to zero, we can say that there is no tendency for the number of mandates to vary as the age of person varies. The Pearson correlation coefficient for this model is very small because $r=0.031$.

\section{The board size and number of mandates}

There is also the opinion expressed in the literature by Ong, Wan and Ong (2003) that the number of directorates is positively correlated with the board size. In order to study this question, two features of the companies were taken into consideration: board size, and the number of directorates per board member. An estimation of the regression line using the least square method for the whole sample of 6,410 companies gives the following result:

$$
\bar{Y}_{c}=a+b X=1.368+0.031 X_{i} .
$$

Such a small value for $b$ indicates that there is no tendency for $Y$ to vary as $X$ varies. The Pearson correlation coefficient for this example is $r=0.096$, which indicates no correlation between the board size and the number of directorates per board member. But, obviously, there is a correlation between the board size and the number of directorates held by the whole board.

The average board age and number of mandates

We can also study the dependency between the average board age and the number of mandates per board member, anticipating that "older boards" possess more mandates per board member. An estimation of the regression line for the same sample of 6,410 companies gives the following result:

$$
\bar{Y}_{c}=a+b X=1.248+0.0068 X_{i} .
$$


We can also say, in this case, that there is no tendency for the number of mandates to vary as the age of the board varies. The coefficient of determination for this model is very small as well, because $r=0.083$.

In the studies which are described in the literature, only big companies are usually taken into consideration. There is a phenomenon observed in the economy that small companies are usually family companies in which the board of directors are often family members. The boards of big companies consist more often of more experienced people. To make these studies comparable with other studies described in the literature, and in order to eliminate family companies in the next step, only big companies, whose boards consist of at least 13 members, are taken into consideration. For every big company we calculated the average age and the number of mandates per board member. The results are shown in Figure 6.

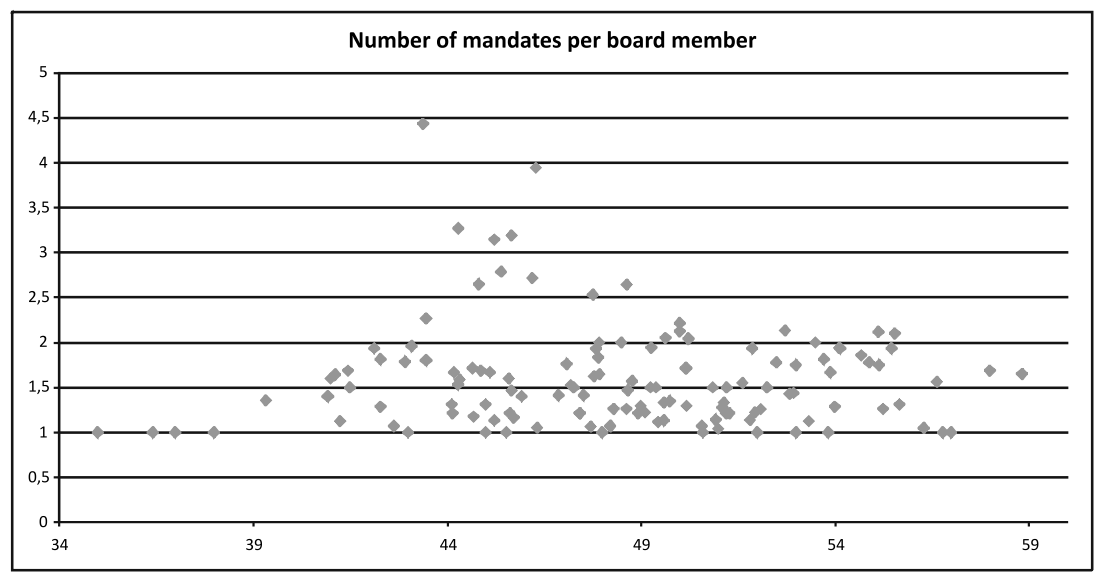

Fig. 9. Average board age and number of mandates per board member for big companies. 
There are only 185 companies in this sample. In this case, there is also no reason to say that there is a dependency between the board's age and the number of mandates.

\section{Number of mandates in different kinds of companies}

Another opinion presented in the literature considers the number of mandates that board members of different kinds of companies possess. Some studies indicate that board members of financial institutions possess more mandates than board members of non-financial institutions (Ong, Wan and Ong (2003). Data from the database enables us to divide the companies into various categories and to study these categories. In order to divide the companies into different groups, the name of company has been used. This is not a precise dividing mechanism, but it may be useful in this particular case.

The following groups of companies have been chosen: 1) banks - companies whose name contains the word 'bank', 2) plants - companies whose name contains the word 'plant', 3) production enterprises - companies whose name contains the word 'production' or 'productions', 4) insurance companies companies whose name contains the word 'insurance', 5) investment funds - companies whose name contains the word 'fund'. The results of the studies of these five groups of companies are shown in Table 1.

As we can see, the groups chosen are not large in comparison with the whole group of 6,410 companies. The average size of the groups chosen is comparable. There is no point in saying that board members of banks possess more mandates than the board members of other groups. What is visible is that banks have a significantly larger board size - two times larger than average for all companies.

Concerning the directors' age, it is possible to say that the oldest boards are in plant and production enterprises. This is not surprising, because this are usually old companies in existence 
Table 1. Interlocking directorates in different kinds of companies.

\begin{tabular}{|l|c|c|c|c|c|c|}
\hline & Banks & Plants & $\begin{array}{c}\text { Produc- } \\
\text { tion } \\
\text { enter- } \\
\text { prises }\end{array}$ & $\begin{array}{c}\text { Insurance } \\
\text { compa- } \\
\text { nies }\end{array}$ & $\begin{array}{c}\text { (Invest- } \\
\text { ments) } \\
\text { funds }\end{array}$ & $\begin{array}{c}\text { All } \\
\text { compa- } \\
\text { nies }\end{array}$ \\
\hline $\begin{array}{l}\text { Number of } \\
\text { companies }\end{array}$ & 42 & 47 & 108 & 67 & 101 & 6410 \\
\hline $\begin{array}{l}\text { Average } \\
\text { board size }\end{array}$ & 12.93 & 6.72 & 6.51 & 8.95 & 6.70 & 6.18 \\
\hline $\begin{array}{l}\text { Aver- } \\
\text { age age } \\
\text { of board } \\
\text { members }\end{array}$ & 47.34 & 49.78 & 51.10 & 46.77 & 43.22 & 47.82 \\
\hline $\begin{array}{l}\text { Number of } \\
\text { directorates } \\
\text { per board } \\
\text { member }\end{array}$ & 1.562 & 1.588 & 1.442 & 2.112 & 2.278 & 1.599 \\
\hline $\begin{array}{l}\text { Number of } \\
\text { connections } \\
\text { with other } \\
\text { companies }\end{array}$ & 7.26 & 3.96 & 2.88 & 9.95 & 8.56 & 3.70 \\
\hline
\end{tabular}

for many years. The youngest boards are in investment funds. These are usually very young companies established after 1989. It must be stressed that during the calculation of the average age, only people who possess a PESEL number were taken into consideration.

The highest number of directorates per board member is in the investment fund and insurance companies. Board members of banks have a similar number of mandates compared to the average of the whole group of 6,410 companies. This is a rather surprising result. It must be stressed that this method of calculation means that some directorates are taken into consideration many times, as the same people are members of different boards. Therefore, the number of mandates per board mem- 
ber for the whole group of 6,410 companies is higher than the number calculated for every person. The second method of calculation (described later) took every directorship into consideration only once. The smallest number of directorates per board member is in production companies. This is, however, not a surprising result. The highest number of mandates in investment fund and insurance companies cannot be explained using the 'bank dominance' theory. Rather, it can be explained using the 'class hegemony' theory.

The highest number of connections with other companies are in insurance companies and investment funds. It is difficult to explain this feature. It may be explained using the class hegemony theory. It must also be stressed that investment funds and insurance companies have the youngest boards.

The results of these studies are partially similar to the results reported by Ong, Wan and Ong (2003). They suggested that the number of directorates is essentially higher for financial institutions. This is true for investment funds and insurance companies, but it is not true for banks.

\section{Changes in subsequent years}

The data collected in the database enable us to study the changes in different indicators in subsequent years. Publication of the BCG started in March 2001, therefore we should omit this first year of publishing in our studies - this year is not comparable as there were only nine months. For the following years, we can study some indicators, and come to some conclusions. For example, the average number of mandates per person possessing at least two mandates is shown in Figure 10.

Knowing the number of mandates for each person we are able to calculate the connections between companies. For example, if a person possesses only one directorship they do not create any connections. If a person possesses two mandates they create one connection. If a person possess three mandates they 


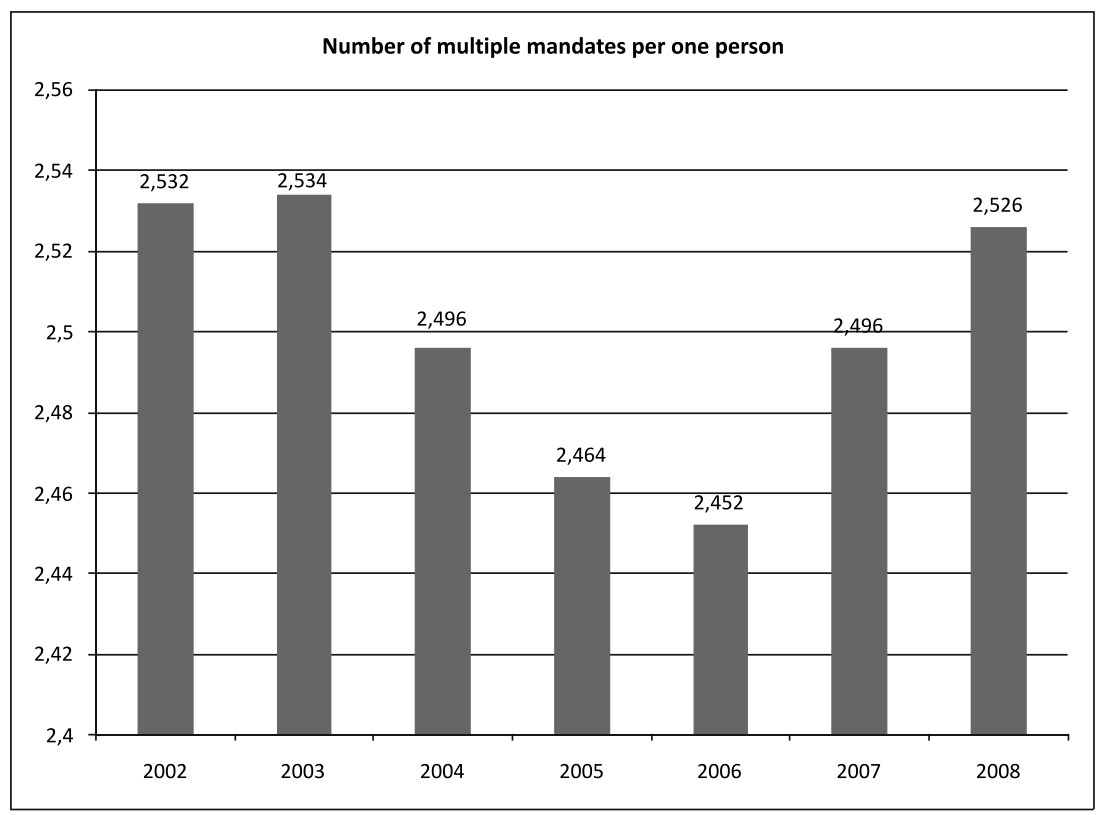

Fig. 10. Number of multiple mandates per person.

create three connections, and so on. In general, we can calculate the number of connections knowing the number of mandates by using the formula:

$$
c_{i}=\frac{n_{i}^{2}-n_{i}}{2},
$$

Where $c_{i}=$ the number of connections created by person $i$, and $n_{i}=$ the number of mandates of person $i$. This calculation formula takes into consideration every connection between companies only once.

The changes in the number of connections per connected company in subsequent years are shown in Figure 11. 


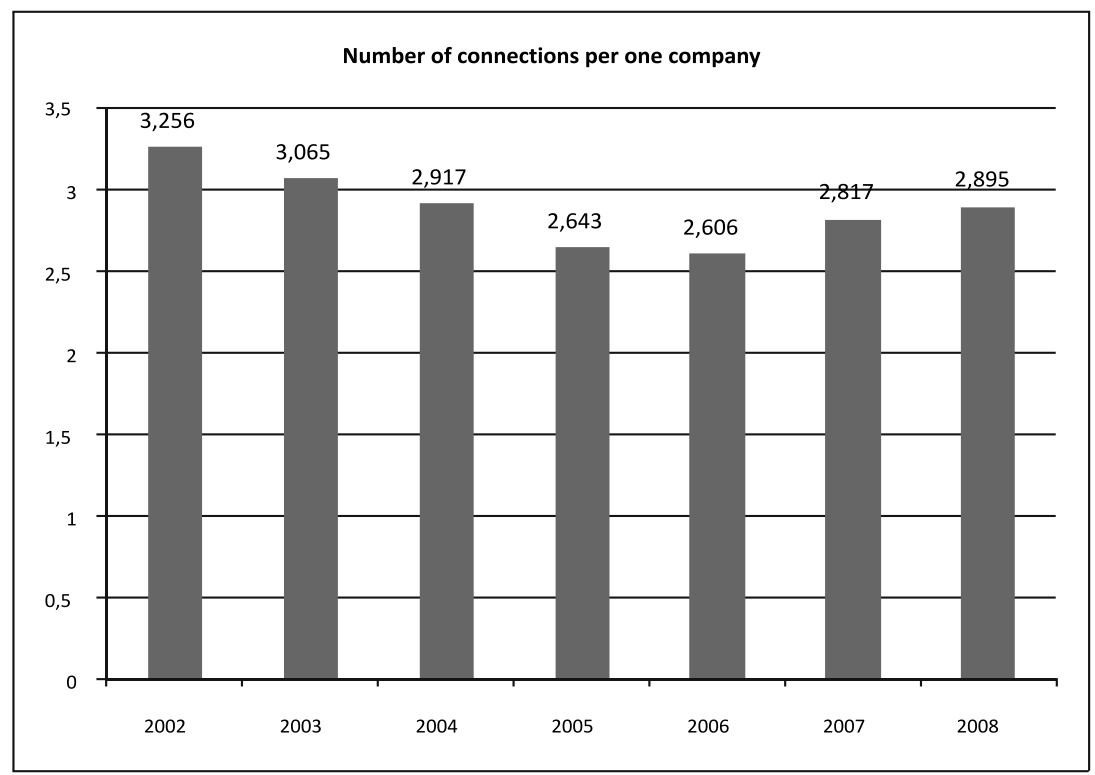

Fig. 11. Number of connections per company in subsequent years.

It is clear that, from the year 2002 until 2006, the number of multiple directorships decreased. After that, from the years 2006 to 2008, the number of interlocking directorships increased. This tendency might be correlated with some general economic indexes, like the Gross Domestic Product.

\section{Female directorates}

Only a part $(86.92 \%)$ of the people who are registered in the database possess a PESEL number which enables us to identify a person's age and sex. About $26 \%$ of the people who possess a PESEL number are women. The percentage of women changes in subsequent years, and this trend is shown in Figure 12. 


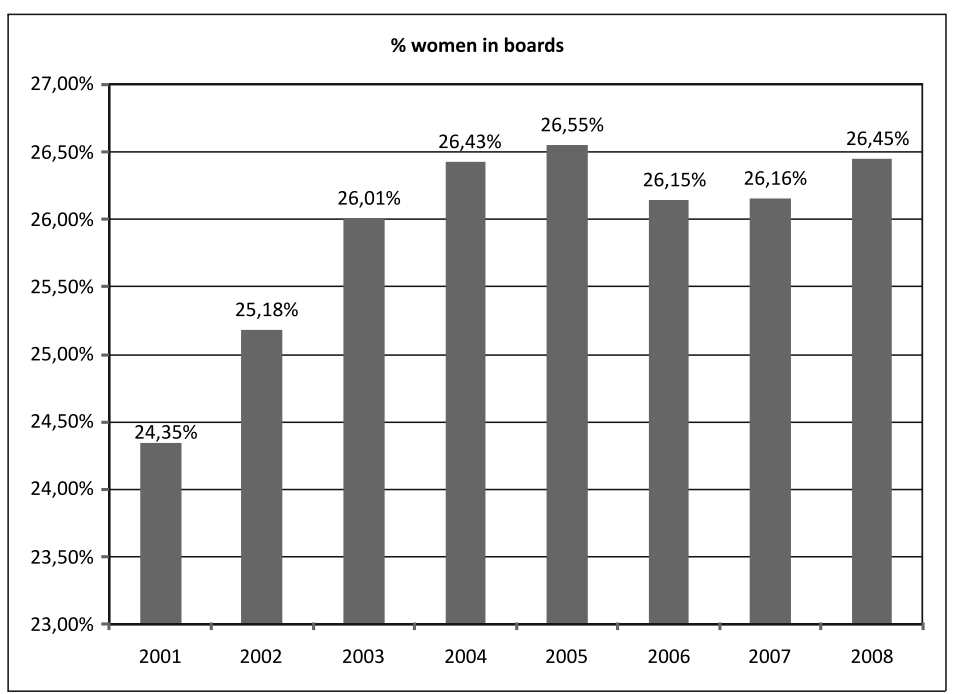

Fig. 12. \% of women in boards.

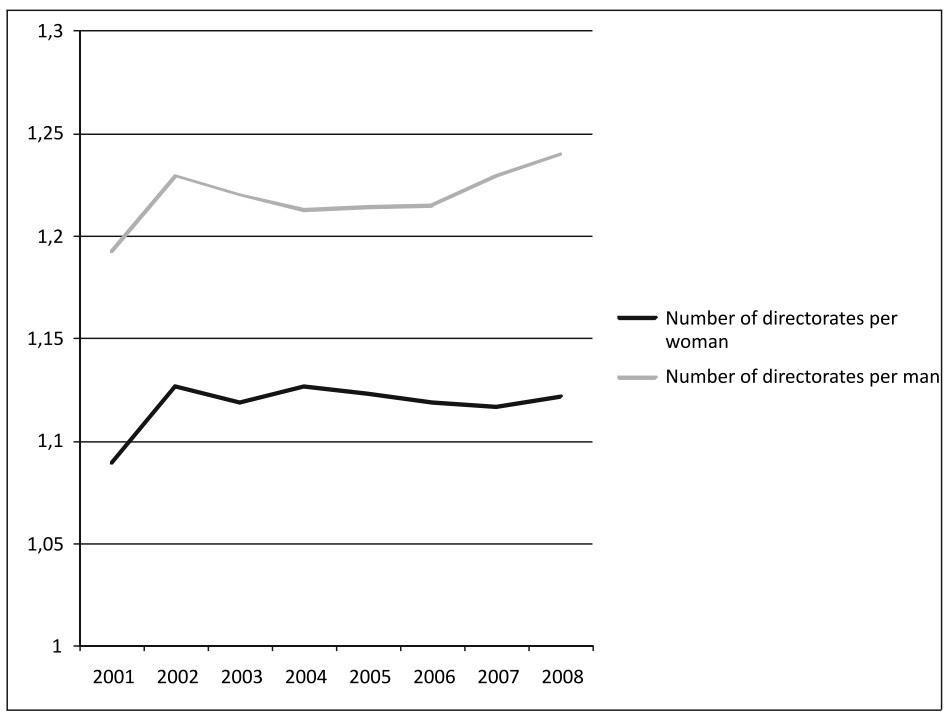

Fig. 13. Number of directorates per woman and per man. 
We are able to compute the number of directorates per man and per woman. This trend is shown in Figure 13.

As we can see, women possess substantially fewer mandates per person (1.122 in 2008) than men (1.240 in 2008). This relationship does not change substantially in subsequent years. Among people who have at least one directorship, $26.45 \%$ are women, but, among people who have at least two directorates, women are only $17.62 \%$ of the total (in 2008).

The relationship between the number of directorates possessed by men and women changes, depending on the number of mandates. This relationship is shown in Figure 14.

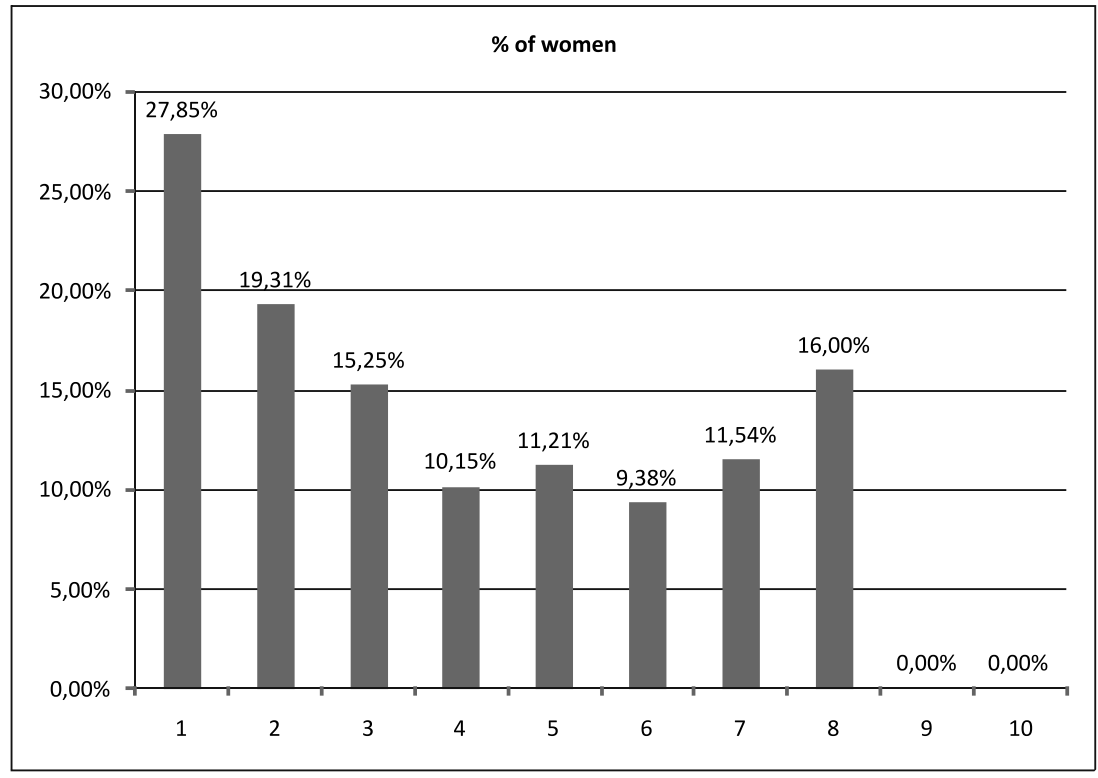

Fig. 14. Number of directorates and \% of women.

As can be seen, among people who possess one directorship $27.85 \%$ are women. This percentage decreases as the number of 
mandates increases. Therefore, we can say that women possess significantly fewer multiple directorates.

The correlation between the number of interlocking directorships and the economic development data

In Figure 15, one indicator is shown which characterises the Polish economy: the total investment as a \% of GDP. There are some similarities between changes in this index and the changes in the number of multiple directorates per person who possess more than one directorship (Figure 10).

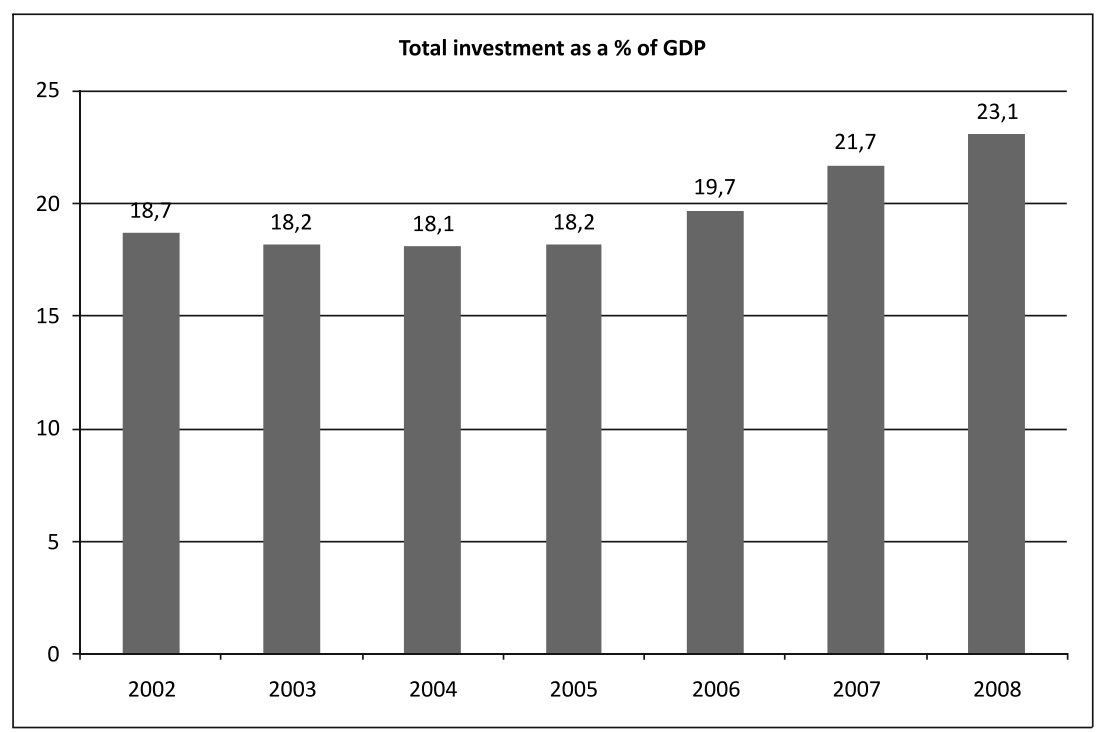

Fig. 15. The total investments as a \% of GDP.

In order to study the relationship between the total investments as a \% of GDP and the number of multiple directorates per board member, we can apply a simple least square regression model. This is shown in Figure 16. 


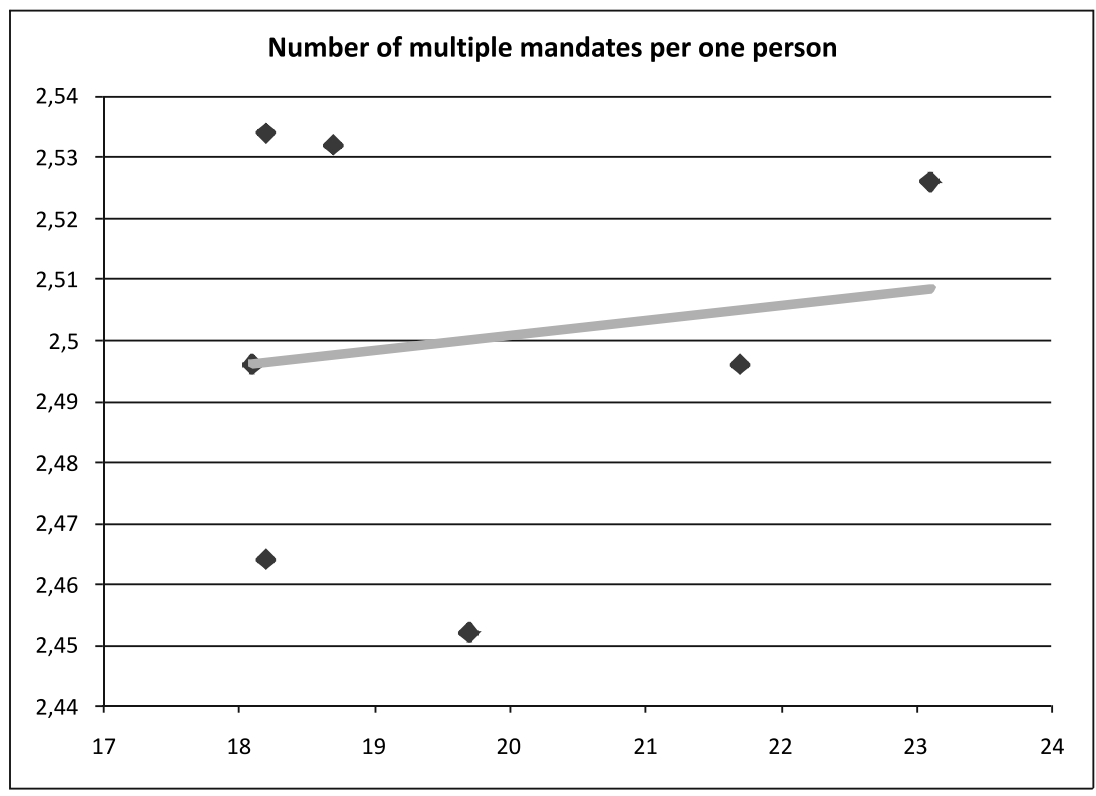

Fig. 16. Total investments and number of directorates.

The calculation of the regression line using the least-squares method gives the following result:

$$
\bar{Y}_{c}=a+b X=2.452+0.0024 X_{i}
$$

The computation of the Pearson $r$ for simple linear correlation gives $r=0.148$. But the $r$ obtained is not significantly different from 0 at the 5 percent level. So we can say that there is no correlation between the total investments as a \% GDP and multiple mandates per person. Similar results arise from the computation of the correlation between the total investments as a \%DP and the number of connections per company. In this case, there is also no correlation. 


\section{CONCLUSIONS}

The phenomenon of interlocking directorships in Polish joint stock companies is comparable with the same phenomenon existing in other countries.

1. The average size of the board of directors in Polish companies is about 6.18. In the big companies studied by Harford (2003) this number is 11.99 .

2. The average age of board members in Polish joint stock companies is about 47.22 for inside directors, and 48.15 for outside directors. It is a relatively young group. For example, in a sample of 1,091 directors from 91 Fortune 1000 firms studied by Harford the mean age of all directors was 59.89 (Harford Jarrad, 2003). In a sample of US corporations studied by Fich and White (2005), the mean age of CEOs was as high as 56.56 .

3. About $26 \%$ of the board members of Polish joint stock companies are women. This concerns only those who possess a PESEL. It is quite a big share. In comparison, in Ireland women held only $4.4 \%$ of the total directorships (Mac Canna Leo, Brennan Niamh, O'Higgins Eleonor, 1998). Women possess on average 1.111 directorates, and men 1.240 directorates per person.

4. About $12.74 \%$ of directors of Polish joint stock companies possess additional directorships. In the sample studied by Harford (2003), 29\% of inside directors and 58\% of outside directors held other directorships, but Harford only studied big companies which are listed in Fortune 1000. In Scotland in 1973, 10.5\% of all directors held two or more directorships (Hughes, Scott, Mackenzie, 1977). The number of multiple directors in Poland is comparable to the number of multiple directors in other European countries studied by Stokman and Wasseur (Mac Canna, Brennan, O’Higgins, 1998). 
5. The average number of directorships for the whole group serving in Polish joint stock companies is 1.20 , and 2.52 for people who hold more than one mandate. In the sample studied by Harford (Harford, 2003), the mean number of additional directorships was 1.94 (inside directors 1.01, outside directors 2.36).

6. There is no correlation between a director's age and the number of mandates. There is no correlation between the board size and the number of mandates per board member. There is no correlation between the 'board age' and the number of mandates per board member.

7. There is no correlation between total investments as a \% of GDP and the number of multiple directorships per board member in Polish joint stock corporations.

\section{REFERENCES}

Barbi, V. (2000). Interlocking directorships networks: what is relevant for the evolution and change of the networks? University of Siena, Department of Economics, Working Paper No. 278.

Bianchi, M., Bianco M., Enriques L.(2001). Pyramidal Groups and the Separation Between Ownership and Control in Italy. The Control of Corporate Europe, edited by Fabrizio Barca, Marco Becht, Oxford University Press, New York.

Brayshay, M., Cleary M., Selwood J. (2006). Power geometries: Social networks and the 1930s multinational corporate elite. Geoforum, Vol. 37 pp. 986-998.

Brickley, J. A., Linck J. S., Coles J. L. (1999). What happens to CEOs after they retire? New evidence on career concerns, horizon problems, and CEO incentives. Journal of Financial Economics, Vol. 52 pp. 341-377.

Burris, V. (1991). Director Interlocks and the Political Behavior of Corporations and Corporate Elits", Social Science Quarterly, Vol. 72, Number 3, pp. 537551.

Carroll, W. K., Alexander Malcolm (1999), Finance Capital and Capitalists Class Integration in the 1990s: Networks of Interlocking Directorships in Canada and Australia. Canadian Review of Sociology \& Anthropology, Aug, Vol. 36 Issue 3, pp. 331-354. 
Fich, E. M., White L. J. (2005). Why do CEOs reciprocally sit on each other's boards? Journal of Corporate Finance, Vol. 11, Issues 1-2, pp. 175-195

Fich, E. M., Shivdasani A. (2007). Financial fraud, director reputation, and shareholder wealth, Journal of Financial Economics, Vol. 86 pp. 306-336.

Harford, J. (2003). Takeover bids and target directors' incentives: the impact of a bid on directors' wealth and board seats, Journal of Financial Economics, Vol. 69 pp. 51-83.

Hughes, M., Scott John, Mackenzie John (1977). Trends in Interlocking Directorships; An International Comparison. Acta Sociologica (Taylor \& Francis Ltd), Vol. 20 Issue 3, pp. 287-292.

Jiraporn, P., Kim Y. S., Davidson, W. N. (2008), Multiple directorships and corporate diversification, Journal of Empirical Finance, Vol. 15. Issue 3, June, pp. 418-435.

Mac Canna, L., Brennan, N., O’Higgins E. (1998). National Networks of Corporate Power: An Irish Perspective, Journal of Management and Governance, Vol. 2, Issue 4, pp. 357-379.

Ong, C. H., Wan, D., Ong, K. S. (2003). An Explanatory Study on Interlocking Directorates in Listed Firms in Singapore, Corporate Governance, Vol. 11, Num. 4, October, pp. 322-334.

Robins, G., Alexander, M. (2004). Small Worlds Among Interlocking Directors: Network Structure and Distance in Bipartite Graphs, Computational $\mathcal{E}$ Mathematical Organization Theory, Vol. 10, pp. 69-94.

Scott, J. (1991). Networks of Corporate Power: A Comparative Assessment Annual Review of Sociology, Vol. 17 Issue 1, pp. 181-203.

Theisen, M. R. (2000). Der Konzern. Betriebswirtschaftliche und rechtliche Grundlagen der Konzernunternehmung. Verlag C. E. Poeschel, Stuttgart. 